\title{
MANAJEMEN PENDIDIKAN PESANTREN AL-ULUM WAL-ALTHOF DALAM MENGUATKAN SIKAP MODERASI BERAGAMA SANTRI
}

\author{
Badrus Soleh dan Iswatul Hasanah \\ Institut Agama Islam Negeri Madura dan Universitan Islam Negeri Malang \\ Email:91badrussoleh@gmail.com dan Iswatulh31@gmail.com
}

\begin{abstract}
Abstrak
Penelitian ini dilakukan karena memiliki tujuan untuk mengetahui tentang fungsi manajemen pendidikan di pesantren Al-Ulum Wal Althof dalam menguatkan moderasi beragama. Jenis penelitian ini adalah penelitian studi kasus (field reseacrh) dengan menggunakan pendekatan kualitatif. Adapun hasil dari penelitian ini adalah: perencanaan pendidikan di pesantren Al-Ulum Wal Althof dalam menguatkan moderasi agama yaitu dengan mendirikan pendidikan formal dan program pondok yang diorganisir oleh pihak sekolah, pengurus pesantren dan kiai dimana pelaksanaannya sesuai dengan jadwal atau peraturan tertulis yang merupakan hasil musyawarah bersama. Pengorganisasian pendidikan pesantren Al-Ulum Wal Althof dipimpin oleh Kiai yang memiliki hak otoritas untuk membagikan tugas pada pihak sekolah dan pengurus pondok pesantren yang kemudian pihak sekolah maupun pengurus pesantren bekerja sama dengan pihak yang terlibat seperti guru. Pelaksanaan pendidikan di pesantren Al-Ulum Wal Althof diatur secara tertulis dan terjadwal agar semua kegiatan baik di pendidikan formal atau di pesantren berjalan dengan baik dan lancar. Pengawasan pendidikan di pesantren Al-Ulum Wal Althof dilakukan oleh pihak sekolah dan pihak pondok pesantren.
\end{abstract}

Kata Kunci: Manajemen, Pendidikan Pesantren, Moderasi beragama

\begin{abstract}
This research was conducted because it aims to find out about the function of education management in Al-Ulum Wal Althof Islamic boarding school in strengthening religious moderation. This type of research is case study research (field research) using a qualitative approach. The results of this study are educational planning at the Al-Ulum Wal Althof Islamic boarding school in strengthening religious moderation, namely by establishing formal education and cottage programs organized by schools, pesantren administrators, and Kiai where the implementation is following the schedule or written regulations which are the result of deliberation. together. The educational organization of the Al-Ulum Wal Althof Islamic boarding school is led by a Kiai who has the right of authority to distribute tasks to the school and boarding school administrators who then the school and the boarding school administrator cooperate with the parties involved such as teachers. The implementation of education at the Al-Ulum Wal Althof Islamic Boarding School is regulated in writing and scheduled so that all activities both in formal education or in pesantren run well and smoothly. Supervision of education at the Al-Ulum Wal Althof Islamic boarding school is carried out by the school and the boarding school.
\end{abstract}

Keywords : Management, Boarding School Education, Religious Moderation 


\section{PENDAHULUAN}

Pemerintah Indonesia khususnya Kementerian Agama telah melakukan beberapa langkah dalam menguatkan moderasi beragama yang memang sudah diberikan amanah langsung dan merupakan program delivery dari presiden untuk benar-benar diseriuskan dalam melaksanakannya. Moderasi beragama merupakan salah satu solusi untuk mempraktikkan ajaran agama dengan jalan tengah atau tidak esktrem dan tidak berlebih-lebihan dalam mengamalkan praktik agama.

Penerapan moderasi beragama dilatar belakangi oleh adanya perbedaan pandangan di kalangan masyarakat dalam mempraktikkan ajaran agama yang memunculkan kesalah pahaman yang kemudian menimbulkan adanya hujatan, saling mencaci, menghasut, dan menyebarkan informasi hoax atau provokasi terhadap pihak lain. Hal tersebut membuat masyarakat tidak mau diatur atau tunduk pada peraturan, merasa dirinya paling benar, paling pintar dan paling tahu. Sehingga sikap itu meyebabkan keretakan terhadap persatuan bangsa dan melahirkan sikap fanatik yang sempit. Dan hal ini lah yang melahirkan adanya paham-paham garis keras atau radikal di Indonesia.

Selain itu, insiden dan konflik yang sering terjadi atas nama agama seperti bom bunuh diri di Surabaya, pembakaran Gereja di Aceh Singkil dan pengeboman di Paris Prancis yang telah merenggut nyawa lebih dari seratus nyawa yang tidak berdosa. ${ }^{1}$ Perbuatan tersebut merupakan perilaku yang tidak manusiawi dan sekan-akan memberi kesan bahwa agama menghalalkan pertumpahan darah, membunuh dan menyakiti orang lain. Padahal agama adalah agama yang ramah dan mengajarkan untuk menyebarkan perdamaian kepada setiap insan.

Indonesia merupakan negara mutikultural yang memiliki keragaman budaya, agama, ras, suku dan bahasa. Perselisihan pasti ada sebab keragaman tersebut namun bukan berarti kekerasan dijadikan pedang untuk menyelesaikan suatu permasalahan justru keragaman yang ada seharusnya dijadikan alat untuk saling melengkapi satu sama lain, memperkuat persatuan dan kesadaran bahwa kita dilahirkan berbeda dan beragam. Dan keragaman merupakan suatu keniscayaan yang tidak bisa dihindari maka diharuskan untuk saling menghormati, bersikap toleransi dan menghargai.

Agama Islam yang merupakan agama yang dianut oleh mayoritas bangsa Indonesia memiliki pedoman hidup berupa Al-Qur'an dan Hadis. Islam mengajak umat Islam untuk berbuat kebajikan dan saling memuliakan melalui ajarannya yang tertuang dalam sebuah hadis "Bertakwalah kepada Allah di mana pun engaku berada. Iringilah keburukan dengan kebaikan, niscaya kebaikan tersebut akan menghapus keburukan. Dan pergauilah manusia dengan ahlak yang mulia". Hadis ini memberi gambaran untuk bersikap baik, hidup rukun, menghargai orang lain dan menjaga keberlangsungan hidup serta menjunjung tinggi perilaku kemanusiaan.

Konflik kekerasan, pengeboman, pembunuhan mencaci maki dan hal buruk lainnya yang mengatas namakan agama telah melanggar peraturan agama dan keluar dari koridor yang sudah diajarkan oleh agama Islam. Insiden yang telah terjadi dikarenakan minimnya pemahaman agama masyarakat sehingga tidak bisa menerima perbedaan, menolak hidup secara berdampingan dengan orang yang berbeda agama dan

\footnotetext{
${ }^{1}$ Samsul AR, "Peran Guru Agama Dalam Menanamkan Moderasi Beragama," Al-Irfan: Journal of Arabic Literature and Islamic Studies 3, no. 1 (2020): 37-51, https://doi.org/10.36835/alirfan.v3i1.3715.
} 
sering menyalahkan perbedaan budaya yang terjadi di lingkungan sekitarnya. Hal ini lah yang menjadi penyebab terjadinya intoleran dan membuat penganutnya bertindak tidak sesuai dengan ajaran agama.

Menyikapi permasalahan di atas, moderasi beragama merupakan kunci untuk menciptakan kerukunan, perdamaian, dan toleransi baik di kalangan umat beragama. Dengan menerapkan atau mengamalkan moderasi beragama masing-masing umat beragama akan bisa bersikap dan memperlakukan orang lain dengan terhormat, menerima perbedaan, serta hidup dalam keadaan damai dan harmoni. Maka penerapan moderasi beragama pada negara multikultural seperti Indonesia merupakan suatu keharusan dan keniscayaan.

Untuk menerapkan moderasi dalam beragama harus memiliki ilmu pengetahuan agama yang baik dan memadai. Dengan ilmu pengetahuan yang luas seseorang akan bisa bersikap bijaksana dalam memilah penafsiran agama yang ekstrem dan tidak hanya melihat satu penafsiran agama saja dan menghindari penafsiran yang lain. Selain ilmu, ahlak yang baik juga harus diaplikasikan, mudah memafkan, menjadi contoh yang baik untuk orang-orang sekitar dan tidak mudah meluapkan emosi sehingga apabila berhadapan dengan permasalahan yang berkaitan dengan agama tidak hanya mengutamakan otot namun memfungsikan akal yang jernih dalam berpikir dan membuat keputusan yang lebih berhati-hati.

Pondok pesantren merupakan lembaga pendidikan Islam yang dikenal sebagai tempat untuk belajar dan memperdalam ilmu agama (tafaqquh fiddin). Kiai sebagai pemimpin sekaligus pembimbing di pesantren terjun langsung untuk mengajar para santri. Kitab kuning merupakan ciri khas yang digunakan oleh santri dalam memperdalam agama dan mengkaji masalah-masalah yang berhubungan dengan Islam. Apabila para santri mengalami kesulitan dalam memahami teks bacaan, mereka langsung bertanya kepada kiai dan kiai pun langsung menjelaskan dengan gamblang. Sehingga hal ini menjadikan para santri tidak tersesat dalam kebingungan dan tidak hanya berdialog dengan pikirannya sendiri.

Pondok pesantren Al-Ulum Wal Althof merupakan pesantren yang menerapkan moderasi agama di kalangan para santrinya. Kiai di pondok tersebut turun tangan secara langsung dalam mengajar dan membina santri agar santri tidak mengalami kesalahan dalam memahami teks keagamaan dengan harapan ketika santri sudah keluar dari pesantren tidak mudah terprovokasi oleh hal-hal baru terutama yang berkaitan dengan agama. untuk meningkatkan moderasi beragama pesantren Al-Ulum Wal Althof juga melakukan tindakan manajemen yang baik di mana Manajemen merupakan proses yang memiliki perencanaan, pengorganisasian, pelaksanaan, dan pengontrolan yang menggunakan ilmu dan seni untuk mencapai sebuah tujuan yang telah ditetapkan. ${ }^{2}$

Maka berdasarkan uraian tersebut, peneliti ingin mengetahui bagaimana manajemen pendidikan pesantren Al-Ulum Wal Althof dalam menguatkan moderasi beragama dari segi perencanaan, pengorganisasian, pelaksanaan dan pengawasannya.

\section{METODE PENELITIAN}

Jenis penelitian ini adalah penelitian studi kasus (field reseacrh) dengan menggunakan pendekatan kualitatif. Adapun teknik pengumpulan data dengan melakukan wawancara, observasi dan studi dokumentasi. Observasi dilakukan dalam

\footnotetext{
${ }^{2}$ George R. Terry, Principle of Management (United State: Richart D. Irwin, Inc, 1977), 4.
} 
beberapa tahapan, diantaranya yaitu observasi awal, dilaksanakan sebelum peneliti melakukan penelitian, dengan mengamati kegiatan yang dilaksanakan di lokasi penelitian yaitu di pesantren Al-Ulum Wal Althof Sampang.

Studi dokumentasi dilakukan pada saat sebelum dan saat pelaksanaan penelitian, yaitu pada saat wawancara dengan para narasumber dan pelaksanaan observasi di pesantren. media yang digunakan saat melakukan dokumentasi yaitu handphone, foto, dan tulisan berupa buku, jurnal, dan dokumen lainnya. Dalam melancarkan penelitian ini, wawancara dilakukan pada narasumber yang berkompeten untuk menjawab persoalan dan permasalahan dalam penelitian ini. Proses wawancara dilaksanakan pada bulan April 2021 terhadap pengasuh muda pesantren dan ketua pondok pesantren.

\section{HASIL DAN PEMBAHASAN \\ Hasil Penelitian}

Melihat pada masalah dan tujuan, hasil dan pembahasan dalam penelitian ini difokuskan pada empat fungsi manajemen yang meliputi perencanaan, pengorganisasian, pelaksanaan dan pengawasan pendidikan pesantren dalam menguatkan moderasi agama di pondok pesantren Al'ulum Wal Althaf. Pesantren AlUlum Wal Althof adalah pesantren salaf yang berlokasi di Sampang Madura, Jawa Timur, Indonesia. Sejak tahun 2019 pesantren Al-Ulum Wal Althof menerapkan pesantren muadalah, yaitu menyelenggarakan pendidikan formal dengan mengembangkan kurikulum kekhasan pesantren yang berbasis kitab kuning. Penguatan moderasi di pesantren Al-Ulum Wal Althof tidak lepas dari strategi manajemen pendidikan yang baik.

\section{Perencanaan Pendidikan Pesantren Al'ulum Wal Althaf}

Akhir-akhir ini sering muncul perang perbedaan pandangan dalam mengimplementasikan ajaran agama Islam baik di media sosial atau kehidupan nyata. Indonesia terdiri dari bangsa yang majemuk, keragaman budaya, suku, dan bahasa. Keragaman tersebut menyebabkan adanya multi tafsir tentang ajaran agama di kalangan bangsa Indonesia. Perbedaan pasti ada namun sebagai bangsa yang menjunjung tinggi nilai-nilai persatuan seharusnya tidak bersikap ekstrem dalam menyikapi suatu perbedaan. Moderasi beragama merupakan cara beragama dengan jalan tengah dan tidak ekstrem. Perencanaan pendidikan yang dilakukan oleh pesantren Al-Ulum Wal Althof dalam meningkatkan moderasi beragama di kalangan pesantren dan santri, adalah pertama, mendirikan pendidikan formal, menetapkan kurikulum yang dijadikan acuan dalam kegiatan pembelajaran, dan sistem pembelajarannya. Kedua, menyelenggarakan program, menentukan program yang akan dijalankan, mengatur jadwal dan pelaksanaannya.

Persiapan dalam membuat perencanaan yang dilakukan oleh pesantren AlUlum Wal Althof yaitu menyetarakan pesantren. Dengan melakukan penyetaraan pesantren (muadalah) yang diakui oleh pemerintah kementerian agama (kemenag), pesantren memiliki wewenang untuk mendirikan pendidikan formal setingkat pendidikan dasar dan menengah, mengatur kurikulum, dan menyelenggarakan program atau kegiatan di pondok pesantren. Persiapan lainnya yaitu mengadakan rapat untuk menentukan tujuan dan sasaran pendidikan yang ingin dicapai.

Tujuan dari perencanaan pendidikan pesantren Al-Ulum Wal Althof yaitu pendalaman ilmu agama dengan melestarikan tradisi-tradisi yang sudah ada sejak dulu, seperti pembelajaran kitab kuning dengan metode sorogan dan bandongan, 
memahamkan pentingnya membangun persatuan untuk menjaga ketahanan tanah air dan keragaman bangsa, serta mendidik santri untuk berpikir kritis dan luas dalam menghadapi suatu perbedaan, mencari alasan-alasan perbedaan tersebut sehingga tidak mudah menjustifikasi sesuatu itu salah.

Pihak yang terlibat dalam pembuatan perencanaan pendidikan pesantren yaitu pengasuh utama atau kiai, para ustaz, kepala sekolah, dan pengurus pondok pesantren. Diharapkan dengan adanya perencanaan yang matang bisa memudahkan dalam setiap kegiatan yang telah ditentukan bersama guna untuk mencapai tujuan secara efektif dan efisien.

\section{Pengorganisasian Pendidikan Pesantren Al'ulum Wal Althaf}

Pengorganisasian merupakan suatu tindakan yang menggabungkan orangorang yang ada dalam organisasi agar bisa bekerjasama sehingga mendapatkan kepuasan pribadi ketika melaksanakan tugas-tugas tertentu guna untuk mencapai tujuan tertentu. Dengan kata lain, pengorganisasian menggerakkan komponen atau pihak yang terlibat dalam organisasi untuk mengerjakan tugasnya demi mencapai tujuan yang sudah ditetapkan. Pengorganisasian yang dilakukan dalam pendidikan pesantren Al-Ulum Wal Althof yaitu membuat struktur organisasi yang berfungsi memudahkan pembagian tugas pada setiap anggota, melatih rasa tanggung jawab setiap anggota dan memudahkan para anggota melakukan koordinasi dan komunikasi. Kiai sebagai pemimpin utama pesantren memiliki peran yang penting dalam mengatur pelaksanaan organisasi. Dan kiai sebagai pemiliki otoritas tertinggi di pesantren melakukan koordinasi dengan semua pihak yang terlibat dalam kepengurusan pendidikan pesantren, membagikan tugas kepada pihak yang terlibat mengelola dan menjalankan kegiatan pendidikan pesantren, serta melaksanakan pendelegasian dalam memberikan tugas untuk melaksakan tugas yang berkaitan dengan pendidikan pesantren.

Pengorganisasian yang dilakukan oleh pihak pesantren berjalan lancar dan optimal, dan hal itu disebabkan adanya solidaritas yang tinggi dari setiap anggota, kesadaran dalam melaksanakan tugas masing-masing anggota serta kepatuhan pada titah pengasuh atau kiai. Keihklasan dalam menjalankan tugas dari semua pihak merupakan cerminan pengharapan keberkahan yang tinggi dari kiai sebagai pengasuh, pendidik, dan guru spiritual.

Komponen yang terlibat dalam pengorganisasian pendidikan di pesantren AlUlum Wal Althof yaitu, kiai sebagai pemimpin utama pesantren, kepala sekolah, wakil kepala sekolah bagian kurikulum dan pengajaran, pengurus pesantren, dan para ustaz. Adanya pengorganisasian dalam pendidikan pesantren berfungsi untuk memudahkan proses koordinasi dengan para pihak, dan melancarkan kerjasama antara anggota yang terlibat dalam implementasi kegiatan pendidikan pesantren.

\section{Pelaksanaan Pendidikan Pesantren Al'ulum Wal Althaf}

Pelaksanaan adalah tindakan nyata yang dilakukan oleh anggota organisasi setelah menetapkan perencanaan yang telah disepakatai demi mencapai suatu tujuan. Pelaksanaan pendidikan di pesantren Al-Ulum Wal Althof diatur dan disusun secara tertulis agar kegiatan yang akan dilaksanakan berjalan lancar dan terarah sesuai dengan pedoman. Pertama, pelaksanaan pendidikan formal dimulai dari awal tahun 
dan dilaksanakan setiap hari. Pelaksanaan pendidikan formal baik tingkat sanawiah (menengah) atau aliah (atas) diklasifikasikan sesuai dengan mata pelajarannya, yaitu kelas kitab yang dikhususkan pelajaran kitab (agama) dan kelas umum yang dikhususkan pelajaran umum. Untuk jadwal hari dan waktu, peneliti sajikan dalam bentuk tabel:

Tabel 1. Jadwal pelaksanaan pendidikan formal pesantren Al-Ulum Wal Althof Sampang

Jenjang Madrasah Tsanawiyah/Aliyah

\begin{tabular}{lll}
\hline JENIS MATA PELAJARAN & \multicolumn{1}{c}{ WAKTU } & \multicolumn{1}{c}{ HARI } \\
\hline KITAB & $07.30-12.00$ & Sabtu-Kamis \\
\hline UMUM & $07.30-10.00$ & Jum'at \\
\hline
\end{tabular}

Pelaksanaan kurikulum pendidikan di pesantren Al-Ulum Wal Althof terdiri dari kurikulum keagamaan Islam yang dikembangkan sesuai dengan kekhasan pesantren yang mengintegrasikan pelajaran kitab dan umum. Berikut kurikulum pendidikan yang diajarkan di pesantren Al'ulum Wal Althaf.

Tabel 2. Sebaran kurikulum pendidikan pesantren Al-Ulum Wal Althof Sampang

1. Jenjang Madrasah Ibtidaiyah

\begin{tabular}{cll}
\hline No & \multicolumn{1}{c}{ Mata Pelajaran } & Kitab Pelajaran \\
\hline 1 & Ilmu Tauhid & Aqidatul 'Awam \\
\cline { 3 - 3 } & & Kifayatul Awam \\
\cline { 3 - 3 } & & Khomsatu Mutun \\
\hline 2 & Fiqih & Surarul Bahiyah \\
\cline { 3 - 3 } & & Safinatun Najah \\
\hline 3 & Ilmu Nahwu & Al- Ajurumiyah \\
\cline { 3 - 3 } & & Al-Imrithi \\
\hline 4 & Ilmu Shorrof & Qmsilatut Tashrifiyah \\
\hline 5 & Ilmu Tajwid & Fathur Rohman \\
\hline 6 & Ilmu Ahlak & Hidayatul Mustafid \\
\hline 7 & Bahasa Arab & Ta'limul Mutaallim \\
\hline 8 & Hadis & Ahlaqu Lil Banat/Lil Banin \\
\hline 9 & Imla' & Madarijud Durus Al-Arabiyah \\
\hline 10 & Ilmu Khot & Lubabul Hadis \\
\hline
\end{tabular}

2. Jenjang Madrasah Tsanawiyah

\begin{tabular}{ccc}
\hline No & Mata Pelajaran & Kitab Pelajaran \\
\hline 1 & Tafsir & Tafsirul Jalalain \\
\hline
\end{tabular}




\begin{tabular}{cll}
\hline 2 & Hadis & Bulughul Maram \\
\hline 3 & Nahwu & Alfiyah Ibnu Malik \\
\hline 4 & Ilmu Tauhid & Ummul Barahin \\
\hline 5 & Fiqih & At-Tahrir . sama \\
\hline 6 & Ilmu Ahlak & 'Idhotun Nasyiin \\
\hline 7 & Ilmu Balaghah & Durusul Balaghah \\
\cline { 2 - 2 } & & Jauharul Maknun \\
\hline 8 & Ilmu Faraid & 'Uddatul Farid \\
\hline 9 & Ushul Fiqih & Ghayatul Ushul \\
\hline 10 & Ilmu Mantiq & Sullamul Munawrok \\
\hline 11 & Mustolah Hadis & Mustolahul Hadis \\
\hline 12 & Tahsinul Khat & - \\
\hline 13 & Qawaidul Fikih & Faraidul Bahiyah \\
\hline 14 & PPKN & - \\
\hline 15 & Biologi & - \\
\hline 16 & IPA & - \\
\hline 17 & Matematika & - \\
\hline
\end{tabular}

\section{Jenjang Madrasah Aliyah}

\begin{tabular}{cll}
\hline No & \multicolumn{1}{c}{ Mata Pelajaran } & \multicolumn{1}{c}{ Kitab Pelajaran } \\
\hline 1 & Tafsir & Tafsirul Jalalain \\
\hline 2 & Hadis & Jamius Shoghir \\
\hline 3 & Nahwu & Alfiyah Ibnu Malik \\
\hline 4 & Ilmu Tauhid & Ummul Barahin \\
\hline 5 & Fiqih & At-Tahrir \\
\hline 6 & Ilmu Ahlak & Adabul 'Alim wa Muta'allim \\
\hline 7 & Ilmu Balaghah & Syarah Jauharul Maknun \\
\hline 8 & Ilmu Faraid & Takmilah \\
\hline 9 & Ushul Fiqih & Ghayatul Ushul \\
\hline 10 & Ilmu Mantiq & Sullamul Munawrok \\
\hline 11 & Mustolah Hadis & Jamius Shoghir \\
\hline 13 & Qawaidul Fikih & Alqowaidul fiqhiyah \\
\hline 14 & PPKN & - \\
\hline 15 & IPA & - \\
\hline 16 & Biologi & - \\
\hline 17 & Matematika & - \\
\hline
\end{tabular}

Pelaksanaan sistem pembelajaran di pesantren Al-Ulum Wal Althof yaitu menggunanakan sistem non klasikal yang terdiri dari sistem bandongan, sorogan dan wetonan. Pelaksanaan sistem non klasikal diberikan ketika melakukan pembelajaran kitab-kitab klasik. Pelaksanaan sistem pembelajaran juga menggunakan sistem klasikal yang diberikan ketika pembelajaran umum berlangsung. 
Kedua, pelaksanaan program pondok pesantren al-Ulum wa al-Thaf. Adapun jenis-jenis program dalam meningkatkan moderasi beragama beserta pelaksanaannya di pesantren Al-Ulum Wal Althof peneliti sajikan dalam bentuk tabel.

Tabel 3. jenis-jenis program dalam meningkatkan moderasi beragama

\begin{tabular}{ll}
\hline \multicolumn{1}{c}{ JENIS PROGRAM } & WAKTU PELAKSANAAN \\
\hline $\begin{array}{l}\text { Belajar bersama (kitab Fathul Mu'in \& tafsir } \\
\text { Jalain) }\end{array}$ & Setiap pagi (harian) \\
\hline Belajar kelompok (sekolah) & Setiap malam (harian) \\
\hline $\begin{array}{l}\text { Kajian kitab (kitab Fathul Mu'in \& tafsir } \\
\text { Jalalain) }\end{array}$ & Setiap pagi (harian) \\
\hline $\begin{array}{l}\text { Kajian kitab (Sullamut Taufiq, Bidayatul } \\
\text { Hidayah, Ta'limul Muta'allim, Mutammimatul } \\
\text { Jurmiyah) }\end{array}$ & Setiap malam (harian) \\
\hline Sholawat bersama & Malam jum'at (mingguan) \\
\hline Tahlil bersama & Malam jum'at (mingguan) \\
\hline Penampilan (pidato, mc, kisah inspiratif) & malam jum'at (mingguan) \\
\hline Bahsul Masail Sughra & Jum'at pagi (mingguan) \\
\hline Bahsul Masail Kubra & Setiap bulan sekali \\
\hline Pengabdian masyarakat & Akhir tahun (tahunan) \\
\hline
\end{tabular}

Penggerakan atau pelaksanaan program di pesantren Al-Ulum Wal Althof diatur oleh pengurus pondok pesantren bagian pengembangan santri yang bekerja sama dengan pengurus pondok lainnya, para ustaz dan ustzah yang ikut membantu menjalankan program di pondok. Tempat pelaksanaan program berlokasi di pondok yang menempati area musholla, kelas, serambi pondok, dan halaman pondok pesantren. pihak yang terlibat dalam pelaksanaan program pondok pesantren adalah pembina program dan santri. Hasil dari pelaksanaan program di pesantren Al-Ulum Wal Althof yaitu santri harus memiliki kedalaman ilmu agama, berjiwa cinta tanah air, menjunjung tinggi persaudaran dan persatuan, memahami adat istiadat yang ada di masyarakat dan tidak mudah terprovokasi terutama dalam masalah agama. Dengan adanya pelaksanaan atau penggerakan terhadap program di pesantren, semua kegiatan yang telah disususn dan diatur diharapkan berjalan sesuai dengan yang diinginkan berdasarkan kesepakatan bersama secara efektif dan efisien.

\section{Pengawasan Pendidikan Pesantren Al'Ulum Wal Althaf}

Pengawasan merupakan fungsi manajemen yang penting untuk mengetahui sejauh mana kegiatan yang telah dilaksanakan, apakah sudah sesuai dengan tujuan yang ingin dicapai atau perlu pembenahan dan perbaikan untuk masa yang akan datang. Maka dalam hal ini pengawasan adalah proses mengarahkan seperangkat variabel atau unsur (manusia, peralatan,mesin, organisasi) kearah tercapainya suatu tujuan atau sasaran manajemen. Pengawasan pada pendidikan di pesantren Al-Ulum Wal Althof mencakup pertama, pengawasan pada kegiatan pendidikan formal, pelaksanaan kurikulum dan sistem pembelajaran dilakukan pada saat kegiatan sekolah berlangsung, ketika proses belajar-mengajar, dan pada saat ada kompetisi sekolah. Sedangkan kedua pengawasan pada program pesantren dilakukan pada saat 
kegiatan atau program sedang berlangsung dan saat santri melakukan aktifitas seharihari. Tujuan pengawasan pada program pondok pesantren adalah agar program yang dilaksanakan oleh santri bisa berjalan dengan baik dan optimal, dan jika terjadi penyimpangan atau kesalahan bisa langsung diatasi dan dibenahi. Dalam melakukan pengawasan pada pendidikan formal maupun program pesantren, tidak ada tahapan khusus, semua kegiatan pengawasan berjalan secara fleksibel, yaitu pada saat kegiatan berlangsung atau dalam aktifitas santri sehari-hari.

Pihak yang terlibat dalam melakukan pengawasan terhadap pendidikan formal dan program di pesantren Al-Ulum Wal Althof yaitu kiai, kepala sekolah, dan wakil kepala sekolah bagian kurikulum, pengurus pondok bagian pengembangan santri, dan para ustaz yang selalu memberi arahan agar kegiatan sekolah maupun pembelajaran berjalan dengan lancar. Manfaat pengawasan pada pendidikan formal dan program di pesantren Al-Ulum Wal Althof adalah untuk mengontrol kegiatan belajar-mengajar, mengetahui perkembangan program yang dilakukan santri dan meneliti apakah kegiatan atau program sudah terlaksana secara efektif atu sesuai dengan tujuan yang ditetapkan.

\section{Pembahasan}

Berdasarkan hasil temuan di atas, pembahasan dalam penelitian ini difokuskan pada empat fungsi manajemen yang meliputi perencanaan, pengorganisasian, pelaksanaan dan pengawasan pendidikan pesantren dalam menguatkan moderasi agama di pondok pesantren Al'ulum Wal Althaf. Pesantren Al-Ulum Wal Althof adalah pesantren salaf yang berlokasi di Sampang Madura, Jawa Timur, Indonesia.

\section{Perencanaan Pendidikan Pesantren Al'ulum Wal Althaf}

Ketika ingin memulai sesuatu alangkah baiknya jika menyusun perencanaan terlebih dahulu. Perencanaan dilakukan agar sesuatu yang akan dilaksankan menjadi jelas dan terarah. Perencanaan dalam pendidikan adalah proses atau aktivitas menetapkan tujuan, tindakan yang akan dilakukan, serta penggunaan sumber daya termasuk penyediaan fasilitas dalam rangka mencapai tujuan lembaga pendidikan secara efektif dan efisien. ${ }^{3}$ Perencanaan pendidikan di pesantren Al-Ulum Wal Althof dalam menguatkan moderasi agama ditentukan atau dibuat oleh pihak pesantren dan pihak sekolah yang melibatkan kiai sebagai pemimpin utama pesantren, kepala sekolah, wakil kepala sekolah bagian kurikulum, para ustaz dan pengurus pesantren. Perencanaan pendidikan di pesantren Al-Ulum Wal Althof dilaksanakan dengan baik sesuai dengan perencanaan yang ditetapkan dan sesuai tujuan yang ingin dicapai, yaitu melalui pendidikan formal santri bisa berpikir kritis dan berwawasan luas, memiliki ilmu agama secara mendalam, memiliki jiwa cinta tanah air dan menjunjung tinggi persatuan bangsa sesuai dengan semboyan pancasila yang berbunyi "bhinneka tunggal ika" meski berbeda-beda tetap satu jua. Tujuan perencanaan pendidikan di pesantren Al-Ulum Wal Althof diperkuat dengan penetapan kurikulum yang didesain dengan perpaduan antara pesantren salaf dan sistem sekolah yang diharapkan akan menghasilkan output pesantren berkualitas yang tercermin dalam sikap aspiratif, progresif dan tidak ortodoks, sehingga dengan hal itu santri mampu beradaptasi dengan cepat terhadap perubahan atau perbedaan dan bisa diterima oleh khalayak atau masyarakat karena tidak bersikap eksklusif atau

\footnotetext{
${ }^{3}$ Suhadi Winoto, Dasar-Dasar Manajemen Pendidikan (Yogyakarta: CV. Bildung Nusantara, 2020), 43.
} 
ekstrem dan memiliki kemampuan yang siap pakai. Dan juga perencanaan pendidikan di pesantren Al-Ulum Wal Althof dalam menguatkan moderasi beragama yaitu dengan menyelenggaraan program pondok pesantren yang yang melibatkan santri dalam melaksanakannya sehingga melalui program tersebut santri akan terbiasa dengan kegiatan yang melibatkan banyak orang yang memiliki sifat atau watak yang berbeda-beda di mana hal itu membuat santri tidak mudah kaget terhadap perbedaan yang ada di kalangan masyarakat. Selain itu program yang diterapkan mengasah kemampuan dan menggali potensi santri sehingga hal itu menjadikan santri berkualitas dan tidak diragukan keilmuannya terutama ilmu agama.

Perencanaan pendidikan di pesantren Al-Ulum Wal Althof disusun dengan penuh pertimbangan dan hasil musyawarah bersama yang kemudian dilaksanakan sesuai dengan tujuan telah yang ditetapkan oleh pihak pesantren dan pihak sekolah yang melibatkan kiai sebagai pemimpin utama pesantren, kepala sekolah, wakil kepala sekolah bagian kurikulum, dan para ustaz.

\section{Pengorganisasian Pendidikan Pesantren Al-Ulum Wal Althof}

Pengorganisasian memiliki peran yang signifikan dalam merancang, membagikan tugas-tugas dan menghubungkan orang-orang yang ada dalam organisasi agar melaksanakan tugas-tugasnya. Pengorganisasian pendidikan di pondok pesantren Al-Ulum Wal Althof dipimpin oleh kiai sebagai pengasuh utama dan kemudia membagikan tugas kegiatan pendidikan pada semua pihak baik pihak sekolah dan pengurus pondok pesantren yang terlibat dalam melaksanakan kegiatan pendidikan, selain memberi tugas, kiai sebagai guru spiritual memperingatkan kepada semua pihak untuk ikhlas dalam melaksanakan tugas agar kegiatan berjalan dengan lancar sesuai dengan perencanaan yang ditetapkan dan tujuan yang ingin dicapai. Fungsi pengorganisasian pendidikan di pesantren al-Ulum wa atl-Thaf yaitu membagikan tugas-tugas pada orang-orang yang terlibat dalam mengelola dan menjalankan kegiatan pendidikan atau program yang ada di pesantren. Hal ini sesuai dengan pendapat Fattah mengenai pengorganisasian yaitu proses membagi kerja ke dalam tugas-tugas yang lebih kecil, membebankan tugas-tugas kepada orang yang sesuai kemampuannya, dan mengalokasikan sumberdaya serta mengkoordinasikannya dalam rangka efektifitas pencapaian tujuan organisasi. ${ }^{4}$

Pembagian tugas untuk semua orang-orang dalam organisasi pesantren mencerminkan sikap 'adil untuk semua pihak yang terlibat dalam pendidikan pesantren. Dan keterlibatan orang-orang dalam pengorganisasian pendidikan di pesantren menunjukkan adanya solidaritas yang tinggi dan menjungjung persaudaraan serta persatuan demi untuk mencapai tujuan yang sudah ditetapkan.

Pengorganisasian pendidikan di pesantren Al-Ulum Wal Althof berjalan dengan baik dan lancar atas bantuan dan kerjasama semua pihak yang terlibat dalam pengorganisasian sesuai dengan bidang yang digeluti oleh masing-masing komponen, dimulai dari kiai, kepala sekolah, wakil kepala sekolah bagian kurikulum, pengurus pondok pesantren, para ustaz dan santri yang mengikuti kegiatan pendidikan pesantren. Semua pihak yang saling bekerjasama dalam pengorganisasian pendidikan di pesantren Al-Ulum Wal Althof mengandung nilai seimbang

\footnotetext{
${ }^{4}$ Nanang Fattah, Landasan Manajemen Pendidikan (Bandung: Remaja Rosdakarya, 2004), 71.
} 
(tawazun). Keseimbangan menjadi suatu keharusan dalam bersosial karena seseorang yang tidak seimbang dalam sosialnya, kehidupan pribadinya dan juga interkasinya maka ia akan rusak. ${ }^{5}$

\section{Pelaksanaan Pendidikan Pesantren Al'ulum wal Althaf}

Pelaksanaan adalah menggerakkan anggota organisasi dan memberi rangsangan agar semangat dan terdorong untuk melaksanakan tugas-tugasnya. Pelaksanaan pendidikan pesantren Al-Ulum Wal Althof dalam meningkatkan moderasi beragama teringkas dalam dua pelaksanaan yaitu pelaksanaan pendidikan formal dan pelaksanaan program/kegiatan di pesantren al-Ulum wa al-Thaf. Pelaksanaan pendidikan formal dan program berjalan dengan baik dan lancar sesuai dengan perencanaan yang ditetapkan. Pelaksanaan pendidikan formal dilakukan oleh santri di lingkungan sekolah yang cukup kondusif dengan adanya fasilitas yang mendukung namun peneliti tidak menemukan perpustakaan di lingkungan sekolah sebagai salah satu sarana dalam meningkatkan wawasan santri. Sedangkan pelaksanaan program atau kegiatan di pesantren Al-Ulum Wal Althof tidak memiliki aula pesantren sehingga program lebih banyak dilaksanakan di musholla. Pelaksanaan kurikulum di pesantren Al-Ulum Wal Althof yaitu mengintegrasikan pelajaran umum dan agama. Integrasi pembelajaran dengan nilai-nilai agama memiliki tujuan yang salah satunya adalah membentuk peserta didik menjadi manusia yang handal dalam mengaplikasikan ilmu yang dimiliki dengan diperkuat oleh spiritualitas yang kokoh. ${ }^{6}$ Nilai-nilai keagamaan oleh pihak sekolah di pesantren Al-Ulum Wal Althof diintegrasikan pada pelajaran kewarganegaraan, matematika, biologi dan IPA. Kemudian, metode pembelajaran yang dilaksanakan di pesantren Al-Ulum Wal Althof yaitu metode bandongan, sorogan dan wetonan. Semua metode ini menciptakan adanya interaksi antara santri dan guru, saling bertukar pikiran dan memberi arahan. Pelaksanaan metode ini mengajak santri untuk berpikir kritis, memahami peristiwa-peristiwa yang ada di sekitar, berupa budaya lokal, adat istiadat masyarakat dan perbedaan yang beragam. Pelaksanaan ini dibantu oleh guru yang membimbing dan memberi arahan. Sebagaimana pelaksanaan terdiri dari memimpin, memberi motivasi, komunikasi, serta menciptakan iklim dan budaya organisasi yang kondusif untuk mencapai tujuan organisasi.

Pelaksanaan program di pesantren berjalan lancar sesuai jadwal yang telah ditetapkan. Untuk melaksanakan program yang lebih optimal, santri menggunakan fasilitas yang ada di pondok berupa musholla, serambi pondok, dan halaman pondok. Melalui program yang telah dilaksanakan diharapkan santri bisa bersikap toleransi ketika melihat perbedaan atau beragamnya sifat dan karakter yang dimiliki santri. Ketika santri bisa menerima perbedaan dalam lingkup kecil maka otomatis bisa mengaplikasikannya dalam lingkup besar. Adanya program bahsul masail, belajar kelompok, dan program yang dilakukan bersama-sama menggambarkan pada santri bahwa hidup dipenuhi beragam manusia yang memiliki karakter berbeda-beda,

\footnotetext{
${ }^{5}$ Kementerian Agama RI, Moderasi Beragama (Jakarta: Balitbang Kementerian Agama RI, 2019), 16.

6 Turmudi, Islam, Sains, Dan Teknologi Menggagas Bangunan Keilmuan Fakultas Sains Dan Teknologi Islami Masa Depan (Malang: UIN Maliki Press, 2006), 15.

${ }^{7}$ St. Rodliyah. Manajemen Pendidikan: Sebuah Konsep dan Aplikasi (Jember:IAINJember Press, 2015), 28.
} 
bahasa, budaya, dan agama. Maka dalam menyikapi perbedaan haruslah moderat tidak ektrem dan inklusif karena perbedaan adalah suatu keniscayaan. Pihak yang terlibat dalam pelaksanaan pendidikan pesantren al-Ulum wal Althaf sangat mendukung dalam meningkatkan moderasi beragama.

\section{Pengawasan Pendidikan di Pesantren Al'ulum wal Althaf}

Pengawasan merupakan tindakan yang memiliki tujuan untuk mengukur, meneliti, dan mengoreksi pelaksanaan kegiatan yang sudah disepakati bersama agar berjalan efektif. ${ }^{8}$ Pengawasan pendidikan di pondok pesantren Al-Ulum Wal Althof meliputi pengawasan terhadap pendidikan formal, proses belajar mengajar, dan pengawasan pada program pondok. Pihak yang berkewajiban mengawasi jalannya lembaga pendidikan formal adalah kepala sekolah, wakil kepala sekolah bagian kurikulum, dan guru/ustaz. Sedangkan yang mengawasi program pondok yaitu, pengurus pondok bidang pendidikan yang bekerjasama dengan semua pengurus. Pengawasan dilaksanakan ketika kegiatan sekolah sedang berlangsung, pada saat proses pembelajaran tengah dijalani. Dan untuk pengawasan program dilakukan ketika santri melaksanakan program atau saat melakukan aktifitas sehari-hari di pondok pesantren. Semua pihak yang berkewajiban mengawasi program atau kegiatan yang sudah ditetapkan melaporkan hasil pengawasan pada kiai sebagai pemimpin utama pesantren.

Pengawasan berarti mengontrol jalannya kegiatan agar mengetahui sejauh mana kegiatan itu dilaksanakan. Dalam mengontrol jalannya kegiatan sekolah, proses belajar mengajar dan kurikulum serta program di pesantren Al-Ulum Wal Althof pihak sekolah dan pondok melakukan review pelaksanaan perbidang apakah sudah terlaksana atau mendapatkan hambatan. Jika dalam proses jalannya kegiatan ditemukan hambatan makan segera dibenahi dan diperbaiki demi untuk meningkatkan kualitas pesantren dan demi mencapai suatu tujuan dan sesuai dengan planning yang ditetapkam. Selain mereview program perbidang, pihak sekolah atau pondok pesantren juga fokus memperhatikan dan mengatasi hambatan yang dihadapi oleh guru, pengurus pesantren, guru/ustaz dan tidak semata-mata mencari kesalahan. Pengawasan yang dilakukan kepala sekolah harus difokuskan perhatian pada usaha mengatasi hambatan yang dihadapi oleh guru atau staf dan tidak semata-mata mencari yang harmonis sehingga tercipta tim kerja yang kompak.

\section{KESIMPULAN}

Perencanaan pendidikan yang dilakukan oleh pesantren Al-Ulum Wal Althof dalam menguatkan moderasi beragama yaitu dimulai dari mendirikan lembaga pendidikan formal yang sudah disetarakan (mu'adalah) dan diakui oleh pemerintah sehingga pesantren bisa mengelola sendiri kurikulum yang akan diterapkan yaitu berupa kurikulum keagamaan Islam yang dikembangkan sesuai dengan kekhasan pesantren yang mengintegrasikan pelajaran kitab dan umum, disertai penerapan sistem pembelajaran khas pesantren berupa sistem sorogan, bandongan dan wetonan. Juga dalam menguatkan moderasi beragama, pesantren Al-Ulum Wal Althof

\footnotetext{
8 Sulistyorini dan Muhammad Fathurrohman. Esensi Manajemen Pendidikan Islam: Pengelolaan Lembaga untuk Meningkatkan Kualitas Pendidikan Islam (Yogyakarta: Kalimedia, 2016), 58.
} 
menyelenggarakan program pondok yang melibatkan santri dalam pelaksanaannya di mana melalui program tersebut santri terbiasa dengan adanya perbedaan di kalangan santri sehingga santri tidak mudah kaget ketika terjun ke masyarakat dan melihat beragam fenomena yang terjadi.

Pengorganisasian pendidikan pesantren Al-Ulum Wal Althof dipimpin oleh kiai di mana kiai memiliki hak otoritas untuk membagikan tugas pada pihak sekolah dan pengurus pondok pesantren yang kemudian pihak sekolah maupun pengurus pesantren bekerja sama dengan pihak yang terlibat seperti guru atau ustaz. Dan hal itu menggambarkan adanya solidaritas yang tinggi dan saling menolong dalam kebaikan.

Pelaksanaan pendidikan di pesantren Al-Ulum Wal Althof dalam meningkatkan moderasi beragama diatur secara tertulis dan terjadwal agar semua kegiatan baik di pendidikan formal atau di pesantren berjalan dengan baik dan lancar. Untuk pendidikan formal pelaksanaannya setiap hari sabtu sampai jum'at. Namun dari sabtu sampai kamis khusus untuk mata pelajaran kitab sedangkan hari jum'at khusus untuk pelajaran umum. Dan pelaksanaan kurikulum diterapkan sebagaimana tujuan yang ingin dicapai oleh sekolah. Integrasi pelajaran kitab dan umum pada kurikulum pendidikan formal merupakan salah satu cara yang ingin dicapai pendidikan pesantren untuk membentuk santri yang memiliki wawasan luas, ilmu agama yang mendalam dan rasa cinta pada tanah air, dan didukung dengan sistem pembelajaran khas pesantren, bandongan, wetonan dan sorogan. Pelaksanaan program psantren dilakukan diluar sekolah yakni ketika santri sudah ada di pondok. Diantara program yang meningkatkan moderasi beragama yaitu program bahsul masail, musyawarah, ajian kitab kuning, sholawat bersama, tahlil bersama dan belajar kelompok. Program tersebut ada yang dilaksanakan mingguan, harian dan bulanan.

Pengawasan pendidikan di pesantren Al-Ulum Wal Althof dilakukan oleh pihak sekolah dan pihak pondok pesantren. Pengawasan pada lembaga formal dilakukan oleh kepala sekolah, wakil kepala sekolah bidang kurikulum, guru atau ustaz. Sedangkaan pada program pondok dilakukan oleh pengurus bidang pendidikan yang bekerjasama dengan pengurus yang lain. kemudian semua komponen yang memiliki tanggung jawab melaporkan hasil pengawasannya kepada kiai sebagai pemimpin utama pesantren. Pengawasan dilaksanakan ketika kegiatan sekolah sedang berlangsung, pada saat proses pembelajaran tengah dijalani. Dan untuk pengawasan program dilakukan ketika santri melaksanakan program atau saat melakukan aktifitas sehari-hari di pondok pesantren.

\section{DAFTAR PUSTAKA}

Abawihda, Ridwan. Kurikulum Pendidikan Pesantren dan Tantangan Perubahan Global. Yogyakarta: Pustaka Pelajar. tt.

Anwar, Ali. Pembaharuan Pendidikan di Pesantren Lirboyo Kediri. Yogyakarta: Pustaka Pelajar, 2011.

AR, Samsul. "Peran Guru Agama Dalam Menanamkan Moderasi Beragama." Al-Irfan : Journal of Arabic Literature and Islamic Studies 3, no. 1 (2020): 37-51. https://doi.org/10.36835/al-irfan.v3i1.3715.

Bahri, Ghazali. Pesantren Berwawasan Lingkungan. Jakarta: CV Prasasti. 2003.

Burhanuddin, Analisis Administrasi Manajemen dan Kepemimpinan Pendidikan. Jakarta. Bumi Aksara. 1994. 
Departemen Agama RI. Moderasi Islam. Jakarta: Lajnah Pentashihan Mushaf alQur'an. 2012.

Dhofier, Zamakhsyari. Tradisi Pesantren: Studi Pandangan Hidup Kyai dan Visinya Mengenai Masa Depan Indonesia. Jakarta: LP3ES. 2015.

Effendi, Unong Uchjana. Human Relation dan Public Relation Dalam Manajemen. Bandung: Alumni. 1986.

Fattah, Nanang. Landasan Manajemen Pendidikan. Bandung: Remaja Rosdakarya, 2004.

Hanawi, Hadari. Administrasi Pendidikan. Jakarta: Gunung Agung. 1981.

Jamal, Nur. "Transformasi Pendidikan Pesantren Dalam Pembentukan Kepribadian Santri”, Jurnal Pendidikan Islam, Vol. 8, Nomor 2, Agusutus 2015.

Kementerian Agama RI. Moderasi Beragama. Balitbang Kementerian Agama RI, 2019.

Latif, Mukhtar dan Suryawahyuni Latief. Teori Manajemen Pendidikan. Jakarta: Prenadamedia Group, 2018.

Maarif, Nurul H. Islam Mengasihi Bukan Membenci. Bandung: PT.Mizan Pustaka, 2017

Misrawi, Zuhairi. Al-Qur'an Kitab Toleransi. Tafsir Tematik Islam Rahmatan Lil 'Alamin. Jakarta: Pustaka Oasis. 2010.

Nahwari, Amiruddin. Pembaharuan Pendidikan Pesantren. Yogyakarta: Gama Media, 2008.

Purwanto, Ngalim, M.P.. Administrasi dan Supervisi Pendidikan. Bandung: Remaja Rosda Karya, 1987

RI, Kementerian Agama. Moderasi Beragama. Jakarta: Balitbang Kementerian Agama RI, 2019.

Shihab, M.Quraisy. Secercah Cahaya Ilahi: Hidup Bersama al-Qur'an. Bandung: Mizan, 2007.

Sugiono. Metodologi Penelitian Pendidikan (Penelitian Kuantitatif, Kualitatif, dan $R$ \& D). Bandung: PT Remaja Rosdakarya Offset. 2010.

Terry, G.R. Asas-asas Manajemen. Alih Bahasa, Winardi, Bandung: Alumni, 1986.

Turmudi. Islam, Sains, Dan Teknologi Menggagas Bangunan Keilmuan Fakultas Sains Dan Teknologi Islami Masa Depan. Malang: UIN Maliki Press, 2006.

Umiarso \& Nur Zain. Pesantren Di Tengah Arus Mutu Pendidikan. Semarang: RaSAIL Media Group, 2011.

Winoto, Suhadi. Dasar-Dasar Manajemen Pendidikan. Yogyakarta: CV. Bildung Nusantara, 2020. 